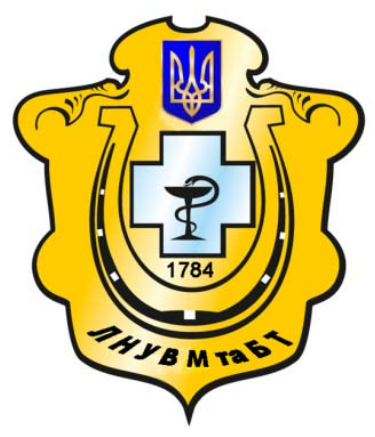

Науковий вісник Львівського національного університету ветеринарної медицини та біотехнологій імені С.3. Гжицького

Scientific Messenger of Lviv National University of Veterinary Medicine and Biotechnologies named after S.Z. Gzhytskyj

doi:10.15421/nvlvet7530

ISSN 2519-268X print

ISSN 2518-1327 online

$\underline{\text { http://nvlvet.com.ua/ }}$

УДК 663.45

\title{
Зниження вмісту віцинальних дікетонів при зброджуванні високогустинного сусла
}

\author{
Т.В. Харандюк, Р.Б. Косів, О.М. Борух, Р.С. Далибожик, Л.Я. Паляниця, Н.І. Березовська \\ tetyanakharandyuk@gmail.com,kosivruslana@gmail.com \\ Національний університет «Львівська політехніка», \\ вул. С. Бандери, 12, м. Львів, 29013, Украӥна
}

\begin{abstract}
Одним із завдань високогустинного пивоваріння як сучасної енергоощадної технологї є отримання пива високої якості, адже смак і аромат напою - його головні споживчі властивості.

Віцинальні дікетони - діачетил (2,3-бутандіон) та 2,3-пентандіон - відіграють значну роль у формуванні смаку. 3авдання пивоварів полягає в зведенні до мінімуму їх утворення або пришвидшенні їх відновлення до речовин із вищим порогом відчуття. До основних методів зниження вмісту дікетонів належать оптимізачія параметрів бродіння та дозрівання, використання модифікованих штамів дріжджів та іммобілізованих дріжджових клітин. Цього досягають також застосуванням ферменту а-ацетолактатдекарбоксилази, який міститься в ферментному препараті Матурекс. Він каталізуе реакиію перетворення $\alpha$-ацетолактату безпосередньо в ацетоїн, минаючи утворення діацетилу. Таким чином значно знижується вміст дікетонів у пиві та скорочується тривалість його дозрівання. В роботі досліджено вплив параметрів зброджування високогустинного сусла - кониентрачії сухих речовин у суслі, температури та тривалості процесу на вміст дікетонів у пиві. Визначено оптимальні умови головного бродіння: концентрачія сусла 16\% сухих речовин, температура бродіння $15{ }^{\circ} \mathrm{C}$, тривалість 7 діб. Встановлено вплив дози ферментного препарату Матурекс 1, 2 i 3 г на 1 гл сусла на вміст віџинальних дікетонів у молодому пиві. Визначено оптимальну дозу препарату, яка становить 2 г на 1 гл сусла. Досліджено вплив ферментного препарату Матурекс на фізико-хімічні показники молодого та готового пива - вміст екстракту та етанолу, рН і кислотність, вміст віцинальних дікетонів.

Таким чином, для пришвидшення прочесів дозрівання пива в технології високогустинного пивоваріння, зниження вмісту віџинальних дікетонів у пиві та збільшення ефективності виробництва можна рекомендувати зброджування сусла конщентрачією $16 \%$ сухих речовин при температурі $15{ }^{\circ} \mathrm{C}$ впродовж 7 діб з додаванням ферментного препарату Матурекс у кількості 2 г на 1 гл сусла.
\end{abstract}

Ключові слова: високогустинне пивоваріння, головне бродіння, дозрівання, віцинальні дікетони, ферментний препарат Матурекс.

\section{Снижение содержания вицинальных дикетонов при сбраживании высокоплотного сусла}

\author{
Т.В. Харандюк, Р.Б. Косив, О.М. Борух, Р.С. Далыбожик, Л.Я. Паляныця, Н.И. Березовская \\ tetyanakharandyuk@gmail.com,kosivruslana@gmail.com
}

Национальный университет «Львовская политехника», ул. С. Бандеры, 12, м. Львов, 29013, Украина

\begin{abstract}
Одной из задач высокоплотного пивоварения как современной энергосберегающей технологии является получение пива высокого качества, ведь вкус и аромат напитка - его главные потребительские свойства.

Вицинальные дикетоны - диачетил (2,3-бутандион) и 2,3-пентандион - играют значительную роль в формировании вкуса. Задача пивоваров заключается в сведении к минимуму их образования или ускорении их восстановления к веществам
\end{abstract}

\section{Citation:}

Kharandiuk, T.V., Kosiv, R.B., Borukh, O.M., Dalybozhyk, R.S., Palianytsia, L.Ya., Berezovska, N.I. (2017). Decreasing of vicinal diketones content during fermentation of high gravity wort. Scientific Messenger LNUVMBT named after S.Z. Gzhytskyj, 19(75), 149-152. 
с высоким порогом ошущения. К основным методам снижения содержания дикетонов принадлежат оптимизаиия параметров брожения и созревания, использование модифицированных штаммов дрожжей и иммобилизованных дрожжевых клеток. Это достигается также применением фермента $\alpha$-ацетолактатдекарбоксилазы, который содержится в ферментном препарате Матурекс. Он катализирует реакцию превращения $\alpha$-ацетолактата непосредственно в ацетоин, минуя образование диацетила. Таким образом значительно снижается содержание дикетонов в пиве и сокрашается продолжительность его созревания. В работе исследовано влияние параметров сбраживания высокоплотного сусла - концентрации сухих веществ в сусле, температуры и продолжительности процесса, на содержание дикетонов в пиве. Определень оптимальные условия главного брожения: концентрация сусла 16\% сухих веществ, температура брожения $15{ }^{\circ} \mathrm{C}$, продолжительность 7 дней. Установлено влияние дозы ферментного препарата Матурекс 1, 2 и 3 г на 1 гл сусла на содержание вицинальных дикетонов в молодом пиве. Определена оптимальная доза препарата, которая составляет 2 г на 1 гл сусла. Исследовано влияние ферментного препарата Матурекс на физико-химические показатели молодого и готового пива - содержание экстракта и этанола, рН и кислотность, содержание вицинальных дикетонов.

Таким образом, для ускорения процессов созревания пива в технологии высокоплотного пивоварения, снижения содержания вицинальных дикетонов в пиве и увеличения эффективности производства можно рекомендовать сбраживание сусла концентрацией 16\% сухих вещуеств при температуре $15{ }^{\circ} \mathrm{C}$ в течение 7 суток с добавлением ферментного препарата Матурекс в количестве 2 г на 1 гл сусла.

Ключевые слова: высокоплотное пивоварение, главное брожение, созревание, вицынальные дикетоны, ферментный nрепарат Матурекс.

\title{
Decreasing of vicinal diketones content during fermentation of high gravity wort
}

\author{
T.V. Kharandiuk, R.B. Kosiv, O.M. Borukh, R.S. Dalybozhyk, L.Ya. Palianytsia, N.I. Berezovska \\ tetyanakharandyuk@gmail.com, kosivruslana@gmail.com
}

National University «Lviv Polytechnic»,

Bandera Str., 12, Lviv, 29013, Ukraine

\begin{abstract}
One of the objectives of high gravity brewing as a modern energy-saving technology is to obtain beer of high quality, because the taste and aroma of the drink - its main properties.

Vicinal diketones - diacetyl (2.3-butandion) and 2.3-pentandion play a significant role in formation of taste. Brewers task is minimizing their formation or accelerating their reduction to substances with a higher threshold of sensation. The main methods to decrease content of diketones are optimization of fermentation and maturation parameters, using of yeast modified strains and immobilized yeast cells. This could also be achieved by use of enzyme a-acetolactate decarboxylase contained in the enzyme preparation Maturex. It catalyses the reaction $\alpha$-acetolactate conversion into acetoin directly without going through the formation of diacetyl. So diketone content in beer is significantly reduced and the duration of its maturation decreased.

In this work we investigated the influence of parameters of high gravity wort fermentation - the wort concentration, temperature and duration of the process on the content of diketones in beer. The optimum conditions for the main fermentation were determined: the wort concentration of $16 \%$, fermentation temperature $15{ }^{\circ} \mathrm{C}$, the duration of 7 days.

The effect of enzyme dosage of Maturex 1, 2 and $3 \mathrm{~g} / 100 \mathrm{~L}$ of wort on the content of vicinal diketones in young beer was studied. The optimum dose of the enzyme preparation was determined, which is 2 grams per $100 \mathrm{~L}$ of wort. The effect of enzyme preparation Maturex on physical and chemical properties of the young and finished beer - content extract and ethanol, $\mathrm{pH}$ and acidity on the content of vicinal diketones was studied.

Therefore, to accelerate the maturation of beer in high gravity brewing technology, to decrease content of vicinal diketones in beer and increase production efficiency recommended parameters of main fermentation are: concentration of wort should be $16 \%$, temperature $15^{\circ} \mathrm{C}$, and duration of the process 7 days with the addition of enzyme preparation Maturex in an amount of $2 \mathrm{~g} / 100 \mathrm{~L}$ of wort.
\end{abstract}

Key words: high gravity brewing, the main fermentation, maturation, vicinal diketones, enzyme preparation Maturex.

\section{Ветуп}

Високогустинне пивоваріння - сучасна енергоощадна технологія пива. Підвищення концентрації зброджуваного сусла дозволяє ефективніше використовувати наявне обладнання, зменшити витрати пари та холоду i, в підсумку, собівартість готового продукту.

Однак при впровадженні цієї технології виникає низка проблем, пов'язаних зі зміною активності дріжджів. Наслідком може бути зміна органолептичних властивостей напою. Дріжджі активують, зокрема, підвищенням температури, яка в свою чергу має суттєвий вплив на склад побічних продуктів бродіння, що формують смаковий профіль готового пива (Kosiv et al., 2016).

Значну роль у формуванні смаку пива відіграють віцинальні дікетони (ВДК), до яких належать діацетил (2,3-бутандіон) та 2,3-пентандіон. Діацетил при перевищенні порогового значення сприйняття 0,10 0,12 мг/дм ${ }^{3}$ зумовлює масляний та неприємний солодкуватий присмак готового пива. Пентандіон завдяки вищому порогу сприйняття 0,6-0,9 мг/дм ${ }^{3}$ має значно менший вплив.

При зброджуванні дріжджі синтезують $\alpha$ ацетолактат, а з нього неферментативним шляхом за межами клітин утворюється діацетил. В міру зниження концентрації кисню в зброджуваному суслі та зменшення інтенсивності розмноження клітин діацетил за участю фермента алкогольдегідрогенази, локалізованого в клітинній стінці дріжджів, перетворюється в ацетоїн і далі в 2,3-бутандіол. Тобто процес редукції діацетилу пов'язаний 3 ферментативною діяльністю дріжджів. 
Кількість утвореного діацетилу залежить від низки факторів (Inoue and Yamamoto, 1970; Boulton and Box, 2003), зокрема величини $\mathrm{pH}$ сусла та температури бродіння (Garcia et al., 1994). Підвищення температури веде до більшого утворення діацетилу на початку процесу як наслідок інтенсифікації росту дріжджів. При цьому нагромаджується більша біомаса дріжджів, яка швидше перетворює діацетил в 2,3-бутандіол (Saerens et al., 2008).

Зниження концентрації діацетилу в зеленому пиві є вартісною і трудомісткою частиною процесу. Тому завдання пивоварів полягає в зведенні до мінімуму утворення діацетилу або прискоренні його відновлення.

До основних методів зниження вмісту ВДК належать оптимізація параметрів бродіння та дозрівання, використання модифікованих штамів дріжджів (Krogerus ana Gibson1, 2013) та іммобілізованих дріжджових клітин (Verbelen et al., 2006).

Зменшення вмісту діацетилу досягають застосуванням ферменту $\alpha$-ацето-лактатдекарбоксилази, який міститься в ферментному препараті (ФП) Матурекс. Він каталізує реакцію перетворення $\alpha$-ацетолактату безпосередньо в ацетоїн, минаючи утворення діацетилу. Таким чином значно знижується вміст ВДК у пиві та скорочується тривалість його дозрівання.

Метою роботи було встановлення ефективності застосування ферментного препарату Матурекс у технології високогустинного пивоваріння.

\section{Матеріал і методи досліджень}

Об'єктами досліджень були пивні дріжджі штаму Saflager W-34/70. Їх культивували в охмеленому стерильному суслі концентрацією $12 \%$ сухих речовин (CР) за схемою:

\begin{tabular}{|c|c|c|c|}
\hline стадія & 1 & 2 & 3 \\
\hline об'єм сусла, см & 10 & 50 & 200 \\
\hline засів & $\begin{array}{c}\text { мікробіологічною } \\
\text { петлею }\end{array}$ & $\begin{array}{c}10 \mathrm{~cm}^{3} \\
31-і ̈ \text { стадіi }\end{array}$ & $\begin{array}{c}60 \mathrm{~cm}^{3} \\
\text { 3 2-ї стадії }\end{array}$ \\
\hline $\begin{array}{l}\text { тривалість } \\
\text { стадії, год. }\end{array}$ & 24 & 24 & 24 \\
\hline
\end{tabular}

Отриману на 3-й стадії біомасу відокремлювали від культурального середовища центрифугуванням впродовж 10 хв. при 4000 хв. $^{-1}$ і застосовували для бродіння.

Для дослідження впливу концентрації сусла, температури і тривалості процесу на вміст ВДК в пиві зброджували $200 \mathrm{~cm}^{3}$ стерильного охмеленого сусла 3 вмістом СР 14, 16 і 18\% при концентрації дріжджів 22,5 млн. клітин в $1 \mathrm{~cm}^{3}$ сусла. Головне бродіння вели при температурах 9, 12 і $15^{\circ} \mathrm{C}$ тривалістю 5, 7 і 9 діб. При дослідженні впливу ФП Матурекс на вміст ВДК в пиві зброджували $16 \%$ сусло при температурі $15{ }^{\circ} \mathrm{C}$ впродовж 5, 6, 7 і 8 діб з додаванням 0 (контроль), 1, 2 i 3 г ФП на 1 гл сусла. Вміст ВДК визначали спектрофотометричним методом (Pfenninger, 2002). 3 метою дослідження впливу ФП Матурекс на якість пива визначали фізико-хімічні показники молодого пива на 7-у добу бродіння та готового пива, отриманих при додаванні 0 (контроль) і 2 г ФП на 1 гл сусла, за прийнятими в галузі методиками (Melet'yev et al., 2008).

\section{Результати та їх обговорення}

При впровадженні технології високогустинного пивоваріння бажаного економічного ефекту досягають зброджуванням сусла підвищеної концентрації, що негативно впливає на метаболізм дріжджів, знижуючи їх бродильну активність. Це призводить до подовження тривалості бродіння, утворення більшої кількості побічних продуктів. 3 метою підвищення активності дріжджів підвищують температуру бродіння, що, в свою чергу, зумовлює нагромадження більшої кількості побічних метаболітів, зокрема діацетилу. Тому важливо дослідити вплив концентрації сусла та температури бродіння на утворення ВДК в процесі головного бродіння (рис. 1).

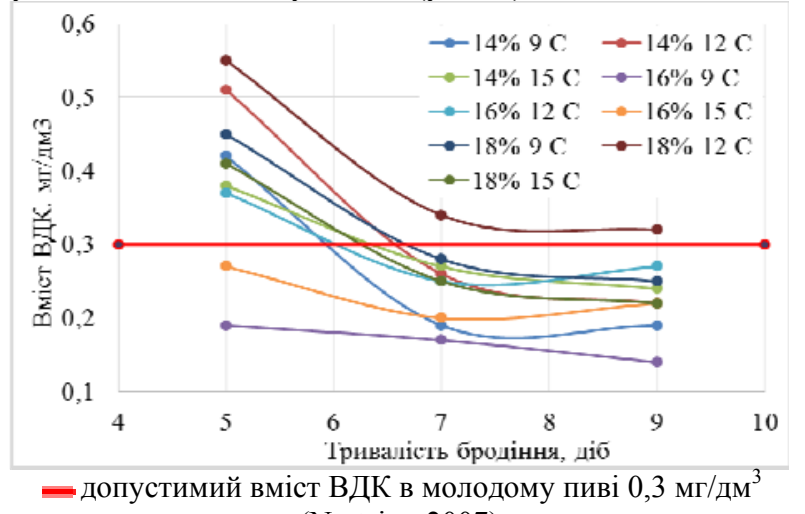
(Nartsiss, 2007)

Рис. 1. Вплив параметрів бродіння на вміст ВДК в молодому пиві

Аналізуючи отримані результати досліджень, встановлено, що впродовж 5-7-ої діб бродіння відбувається редукція ВДК зі зменшенням їх вмісту. Подовження процесу до 9 діб не впливає на вміст дікетонів у молодому пиві.

Найнижчий вміст ВДК спостерігали при температурі бродіння $9{ }^{\circ} \mathrm{C}$. Проте вона несприятлива для зброджування високогустинного сусла, оскільки при цьому значно знижується бродильна активність дріжджів (Kharandyuk and Kosiv, 2015), а, отже, зростає тривалість процесу.

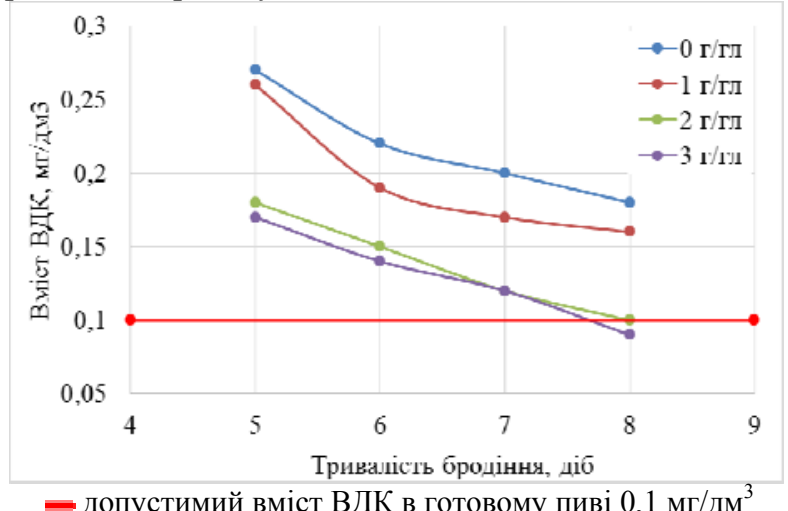

- допустимий вміст ВДК в готовому пиві 0,1 мг/дм ${ }^{3}$ (Nartsiss, 2007)

Рис. 2. Вплив дози препарату Матурекс на вміст ВДК в молодому пиві 
Підвищення температури до $15^{\circ} \mathrm{C}$ сприяло розмноженню дріжджів і в результаті швидшій редукції ВДК дріжджовими клітинами. Низького вмісту ВДК в молодому пиві 0,2 мг/дм ${ }^{3}$ було досягнуто при зброджуванні сусла концентрацією $16 \%$ СР при температурі $15^{\circ} \mathrm{C}$.

Враховуючи, що в готовому пиві порогове значення ВДК становить 0,1 мг/дм³, редукція ВДК від значення 0,2 до $0,1 \mathrm{мг} /$ дм $^{3}$ спричинятиме тривале дозрівання пива, що зменшуватиме ефективність його виробництва. Тому доцільно дослідити вплив ФП Матурекс при дозуванні 1, 2 і 3 г ФП на 1 гл сусла на вміст ВДК в молодому пиві, порівнюючи 3 контрольним зразком, до якого ферментний препарат не додавали (рис. 2). Як показали результати досліджень, збільшення дози ферментного препарату від 1 до 2 г/гл призводило до зниження вмісту ВДК в молодому пиві. Подальше підвищення дози не мало суттєвого впливу. Тому оптимальною дозою ФП є 2 г/гл, при якій вже на 6-у добу бродіння значно знижувалась концентрація ВДК в молодому пиві до 0,15 мг/дм ${ }^{3}$, а на 8-у добу досягала значення, характерного для готового пива $-0,1$ мг/дм ${ }^{3}$.

При впровадженні змін у технологію пивоваріння важливо, щоб якісні показники пива не погіршувались. 3 цією метою контролювали фізико-хімічні показники молодого та готового пива (табл.).

Фізико-хімічні показники молодого та готового пива

\begin{tabular}{|c|c|c|c|c|}
\hline \multirow{3}{*}{ Показники } & \multicolumn{2}{|c|}{ Молоде пиво } & \multicolumn{2}{|c|}{ Готове пиво } \\
\hline & \multicolumn{2}{|c|}{ Доза ФП, г/гл } & \multicolumn{2}{|c|}{ Доза ФП, г/гл } \\
\hline & 0 & 2 & 0 & 2 \\
\hline Концентрація сусла, \% СР & 16,30 & 16,23 & 16,30 & 16,23 \\
\hline Вміст етанолу, \% об. & 6,80 & 6,82 & 7,22 & 7,23 \\
\hline $\begin{array}{l}\text { Вміст екстракту, \% мас.: } \\
\text { видимий } \\
\text { дійсний }\end{array}$ & $\begin{array}{l}3,35 \\
5,72\end{array}$ & $\begin{array}{l}3,32 \\
5,69\end{array}$ & $\begin{array}{l}3,18 \\
5,54\end{array}$ & $\begin{array}{l}3,19 \\
5,59\end{array}$ \\
\hline Вміст ВДК, мг/дм ${ }^{3}$ & 0,20 & 0,12 & 0,15 & 0,08 \\
\hline $\mathrm{pH}$ & 4,54 & 4,55 & 4,49 & 4,52 \\
\hline Кислотність, см ${ }^{3} 1$ н $\mathrm{NaOH} / 100 \mathrm{~cm}^{3}$ & 2,3 & 2,3 & 2,3 & 2,3 \\
\hline
\end{tabular}

Результати досліджень засвідчили, що всі зразки готового пива відповідали вимогам стандарту, додавання ферментного препарату Матурекс не впливало на фізико-хімічні показники молодого та готового пива - вміст екстракту та етанолу, $\mathrm{pH}$ і кислотність, а лише дозволяло знизити вміст ВДК.

\section{Висновки}

Отримання напою високої якості - важливе завдання технології пива, зокрема високогустинного пивоваріння як сучасної енергоощадної технології. Значну роль у формуванні смаку пива відіграють віцинальні дікетони. 3 метою зниження їх вмісту у пиві та пришвидшення процесів його дозрівання в технології високогустинного пивоваріння, збільшення ефективності виробництва рекомендується зброджувати сусло концентрацією $16 \%$ сухих речовин при температурі $15{ }^{\circ} \mathrm{C}$ впродовж 7 діб з додаванням ферментного препарату Матурекс у кількості 2 г на 1 гл сусла.

\section{Бібліографічні посилання}

Kosiv, R., Kharandiuk, T., Polyuzhyn, L., Palianytsia, L., Berezovska, N. (2016). Optimization of Main Fermentation of High-Gravity Wort. Chemistry and Chemical Technology. 10(3), 349-353.

Boulton, C., Box, W. (2003). Formation and disappearance of diacetyl during lager fermentation, in Brewing Yeast Fermentation Performance. Smart, K. Ed. Blackwell Science: Oxford, 183-195.
Inoue, T., Yamamoto, Y. (1970). Diacetyl and beer fermentation. Proc. Am. Soc. Brew. Chem. 28, 198208.

Garcia, A., Garcia, L., Diaz, M. (1994). Modelling of diacetyl production during beer fermentation. J. Inst. Brew. 100, 179-183.

Saerens, S., Verbelen, P., Vanbeneden, N., Thevelein, J., Delvaux, F. (2008). Monitoring the influence of highgravity brewing and fermentation temperature on flavour formation by analysis of gene expression levels in brewing yeast. Appl. Genet. Mol. Biotechnol. 80, 1039-1051.

Krogerus, K., Gibson1, B. (2013). Diacetyl and its control during brewery fermentation. The Institute of Brewing \& Distilling. 119, 86-977.

Verbelen, P., de Schutter, D., Delvaux, F., Verstrepen, K., Delvaux, F.R. (2006). Immobilized yeast cell systems for continuous fermentation applications. Biotechnol. Lett. 28, 1515-1525.

Pfenninger, H. (2002). Methods collection of the Mitteleuropäischen Brautechnischen Analysenkommision. MEBAK, 134.

Melet'yev, A.C., Todosiychuk, S.R., Koshova, V.M. (2008). Tekhnokhimichnyy kontrol' solodu, pyva ta bezalkohol'nykh napoyiv. Vinnytsya: Nova knyha (in Russian).

Nartsiss, L. (2007). Kratkiy kurs pivovareniya. SPb: Professiya (in Russian).

Kharandyuk, T.V., Kosiv, R.B. (2015). Vplyv temperatury na brodyl'nu aktyvnist' pyvnykh drizhdzhiv. Odesa: Zbirnyk naukovykh prats' molodykh uchenykh, aspirantiv ta studentiv. 157 (in Ukrainian). 